\title{
On the Fenton degradation mechanism. The role of oxalic acid
}

\author{
Yamila Alegría ${ }^{\mathrm{a}}$, Fernando Liendo, ${ }^{\mathrm{b}}$ and Oswaldo Núñez ${ }^{\mathrm{a} *}$ \\ ${ }^{a}$ Laboratorio de Química Ambiental, Departamento de Procesos y Sistemas. Universidad Simón \\ Bolívar. Apartado postal 89000. Caracas, Venezuela. ${ }^{b}$ Gerencia de Ecología y Ambiente. \\ PDVSA Intevep. Apartado postal 76343. Caracas, 1070A, Venezuela \\ E-mail: onunez@usb.ve
}

\section{Dedicated to Professors Roberto A. Rossi on his $60^{\text {th }}$ anniversary and Edmundo A. Ruveda on his $\mathbf{7 0}^{\text {th }}$ anniversary \\ (received 19 Aug 03; accepted 12 Nov 03; published on the web 04 Dec 03)}

\begin{abstract}
Kinetics of Fenton ( $\mathrm{Fe}(\mathrm{II})+\mathrm{H}_{2} \mathrm{O}_{2}$ ) p-nitrophenol degradation reveal that the measured pseudo first-order rate constant is given by the expression: kobs $=\mathrm{kK}\left[\mathrm{H}_{2} \mathrm{O}_{2}\right] /\left(1+\mathrm{K}\left[\mathrm{H}_{2} \mathrm{O}_{2}\right]\right)$, where $\mathrm{K}=$ $20.3 \times 10^{2} \mathrm{M}^{-1}$ is the equilibrium constant of formation of the complex $\mathrm{Fe}(\mathrm{II})-\left(\mathrm{H}_{2} \mathrm{O}_{2}\right)_{\mathrm{n}}$ and $\mathrm{k}=1.5$ $\times 10^{-2} \mathrm{~s}^{-1}$ is the first order rate constant of degradation of the complex to yield Fe (III), $\mathrm{OH}$ and $\mathrm{OH}^{-}$. When oxalic acid is added, the complex $\mathrm{Fe}(\mathrm{III})$-oxalic acid- $\mathrm{H}_{2} \mathrm{O}_{2}$ is formed producing a highly oxidized Fe(IV) species as the primary oxidant agent.
\end{abstract}

Keywords: Fenton, $p$-nitrophenol, pseudo first-order, Fe(III)-oxalic acid-complex

\section{Introduction}

The Fenton reagent ${ }^{1}\left(\mathrm{Fe}(\mathrm{II}) / \mathrm{H}_{2} \mathrm{O}_{2}\right)$ constitutes one of the so called Advanced Oxidation Process (AOP's) that has been used for the decontamination of organic pollutants from water. This process application in water treatment is widely recognized. For instance, we have treated ${ }^{2}$, at the laboratory scale, typical oil industry effluents from production and petrochemical activities as well as artificial water samples containing: $m$-cresol, 2-chlorophenol, methyl tert-butylether and reformulated gasoline. The Fenton reagent has been also used to degrade organic chlorides, pesticides, monocyclic aromatics as well to reduce the COD (chemical oxygen demand) of municipal waters ${ }^{3-9}$. It also has been used in the decontamination of soils ${ }^{10}$.

It has been proposed ${ }^{11-14}$ that the reaction mechanism involves formation of the hydroxyl radical in a rate limiting step (Eq.1) with further diffusion-controlled rate radical attack to the organic substrate. 


$$
\mathrm{Fe}^{+2}+\mathrm{H}_{2} \mathrm{O}_{2} \rightarrow \mathrm{Fe}^{+3}+\mathrm{OH}^{-}+\mathrm{OH}^{\cdot}
$$

It has been also proposed ${ }^{14}$ that a highly oxidized intermediate is formed previous to the hydroxyl radical formation (Eq. 2).

$$
\mathrm{Fe}^{+2}+\mathrm{H}_{2} \mathrm{O}_{2} \rightarrow(\mathrm{FeOH})^{+3}=\mathrm{Fe}^{+3}+\mathrm{OH}^{\cdot}
$$

Besides hydroxyl radical, as the primary oxidant, a higher valence iron (Eq.3) or iron-oxygen complex ${ }^{15,16,17}$ has been proposed. In the last case, intramolecular oxidation-reduction is presented as evidence of $\mathrm{Fe}$ (IV) intermediate.

$$
\mathrm{Fe}^{+2}+\mathrm{H}_{2} \mathrm{O}_{2} \rightarrow \mathrm{FeO}^{2+}+\mathrm{H}_{2} \mathrm{O}
$$

In this paper we focus on the detailed mechanism of the hydroxyl radical formation and explore practical conditions that accelerate and retard the reaction. Kinetic evidence for a preequilibrium between free reactants and its complex previous to the rate limiting hydroxyl radical formation is presented. Reaction is improved when oxalic acid is added to the reaction. A new path (besides the hydroxyl radical one) is then contributing to the oxidation. Important evidence in favor of the participation of a highly oxidized iron species are given by monitoring COD (chemical oxygen demand) during reaction progress.

\section{Results and Discussion}

\section{Experiments changing $\left[\mathrm{H}_{2} \mathrm{O}_{2}\right]$}

In Table 1, pseudo first-order rate constants, at different $\left[\mathrm{H}_{2} \mathrm{O}_{2}\right]$ ratios, obtained from plots of $\mathrm{ln}$ [p-nitrophenol] vs. $t$ are shown. In Figure 1 , the obtained $\mathrm{k}_{\text {obs. }}$ values are plotted vs. $\left[\mathrm{H}_{2} \mathrm{O}_{2}\right]$.

Table 1. Pseudo first-order rate constants at different $\left[\mathrm{H}_{2} \mathrm{O}_{2}\right]$. T: $25^{\circ} \mathrm{C} ; \mathrm{pH}=2.8$. kobs. deviation values obtained from triplicates

\begin{tabular}{ccc}
\hline $\begin{array}{c}\text { Ratio } \\
\left(p \text {-Nitrophenol: } \mathrm{H}_{2} \mathrm{O}_{2}: \mathrm{Fe}(\mathrm{II})\right)\end{array}$ & $\begin{array}{c}{\left[\mathrm{H}_{2} \mathrm{O}_{2}\right] \times 10^{3}} \\
(\mathrm{M})\end{array}$ & $\begin{array}{c}\mathrm{k}_{\mathrm{obs}} \times 10^{3} \\
\left(\mathrm{~s}^{-1}\right)\end{array}$ \\
\hline $1: 5: 1$ & 0.5 & $8.1 \pm 0.3$ \\
$1: 8: 1$ & 0.8 & $8.7 \pm 0.4$ \\
$1: 14: 1$ & 1.4 & $12.4 \pm 0.1$ \\
$1: 17: 1$ & 1.7 & $12.5 \pm 0.6$ \\
$1: 20.1$ & 2 & $12.0 \pm 0.3$ \\
\hline
\end{tabular}




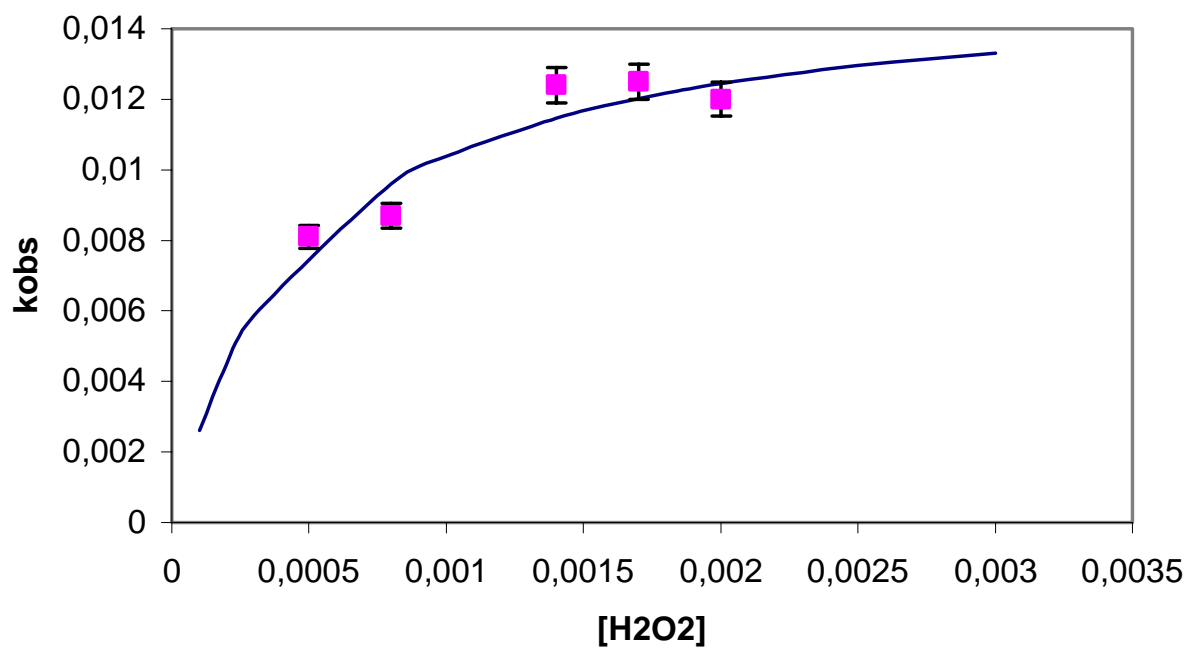

Figure 1. Plot of pseudo-first order rate constants $\left(\mathrm{k}_{\mathrm{obs}}\right)$ vs. $\left[\mathrm{H}_{2} \mathrm{O}_{2}\right] . \mathrm{T}=25{ }^{\circ} \mathrm{C} . \mathrm{pH}=2.8$. Experimental points and error (4\%) bars from triplicates are shown. Continuous line corresponds to Eq. 5 theoretical values, with $\mathrm{k}=0.015 \mathrm{~s}^{-1}$ and $\mathrm{K}=2034 \mathrm{M}^{-1} . \mathrm{k}$ and $\mathrm{K}$ values were obtained from a plot of $1 /$ kobs vs. $1 /\left[\mathrm{H}_{2} \mathrm{O}_{2}\right]$ (Figure 2).

The $\mathrm{k}_{\text {obs. }}$ vs. $\left[\mathrm{H}_{2} \mathrm{O}_{2}\right]$ profile, corresponds to a pseudo first-order mechanism in which an equilibrium prior to the rate limiting step is established as shown in Eq. 4. Eq. 5, shows the corresponding rate law.

$$
\begin{aligned}
& \mathrm{Fe}^{+2}+\mathrm{n} \mathrm{H}_{2} \mathrm{O}_{2} \stackrel{\mathrm{K}}{\longleftrightarrow} \mathrm{Fe}-\left(\mathrm{H}_{2} \mathrm{O}_{2}\right)_{\mathrm{n}} \stackrel{\mathrm{k}}{\longleftrightarrow} \mathrm{Fe}^{+3}-\left(\mathrm{H}_{2} \mathrm{O}_{2}\right)_{\mathrm{n}-1}+\mathrm{HO}^{-}+\mathrm{HO}^{\bullet} \\
& \text { where, } \\
& \qquad \mathrm{k} \mathrm{obs}=\frac{\mathrm{K} \mathrm{k}\left[\mathrm{H}_{2} \mathrm{O}_{2}\right]}{1+\mathrm{K}\left[\mathrm{H}_{2} \mathrm{O}_{2}\right]}
\end{aligned}
$$

In Figure 2, a plot of $1 / \mathrm{kobs}$ vs. $1 /\left[\mathrm{H}_{2} \mathrm{O}_{2}\right]$ is shown. From the intercept, a $\mathrm{k}=0.0155 \mathrm{~s}^{-1}$ is directly obtained and from the slope (slope $=1 / \mathrm{kK}$ ), $\mathrm{K}=2034 \mathrm{M}^{-1}$ is found. These values were used to simulate, using Eq. 5, the predicted kobs at different $\left[\mathrm{H}_{2} \mathrm{O}_{2}\right]$ (Figure 1, continuous line). According to Eq. 5 when $1>\mathrm{K}\left[\mathrm{H}_{2} \mathrm{O}_{2}\right]$, kobs $=\mathrm{kK}\left[\mathrm{H}_{2} \mathrm{O}_{2}\right]$; from where a $\mathrm{kK}=31.5 \mathrm{~s}^{-1} \mathrm{M}^{-1}$ is obtained. 


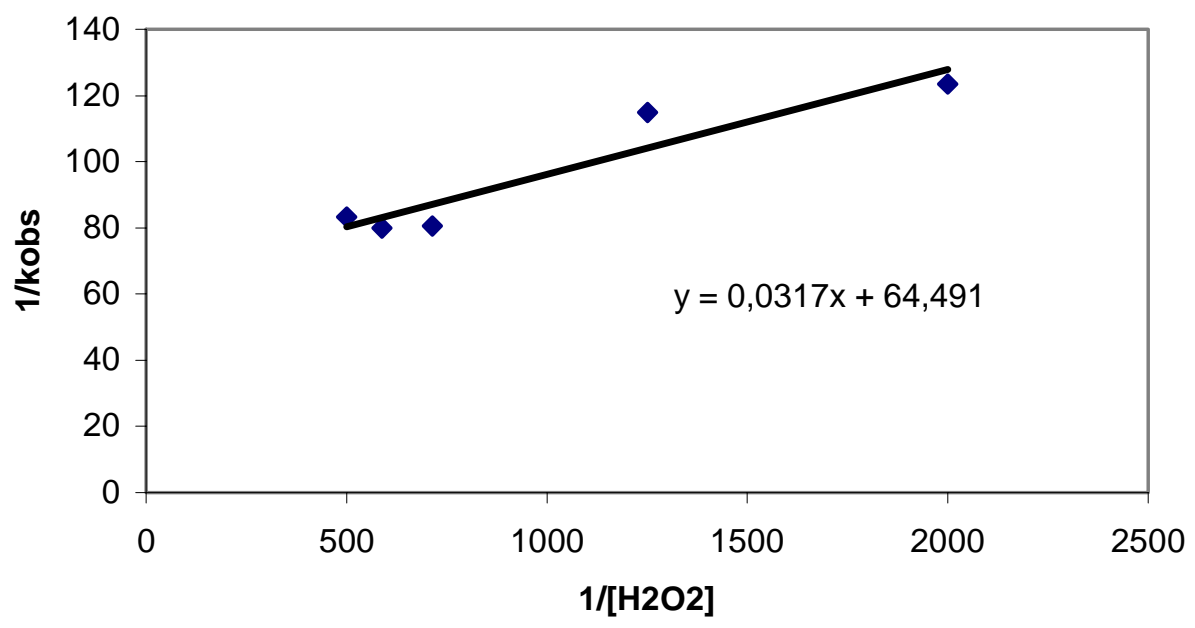

Figure 2. $1 /$ kobs vs. $1 /\left[\mathrm{H}_{2} \mathrm{O}_{2}\right]$. From the intercept $=64.49=1 / \mathrm{k}, \mathrm{k}=0.0155 \mathrm{~s}^{-1}$ is obtained and from the slope $=0.031=1 / \mathrm{kK}, \mathrm{K}=2034 \mathrm{M}^{-1}$ is found.

Using a $\mathrm{Fe}(\mathrm{II}): \mathrm{H}_{2} \mathrm{O}_{2}(1: 14)$ ratio and following the appearance of the $\mathrm{Fe}(\mathrm{III}) \mathrm{UV}$ band at 220 $\mathrm{nm}$, a pseudo first-order rate constant of $2.4( \pm 0.3) \times 10^{-2} \mathrm{~s}^{-1}$, similar to the value obtained from Figure 1 is found. When $\mathrm{Fe}(\mathrm{III})$ is used instead of $\mathrm{Fe}(\mathrm{II})$ with initial ratios: $p$ nitrophenol: $\mathrm{H}_{2} \mathrm{O}_{2}: \mathrm{Fe}(\mathrm{III})=1: 5: 1$, following the UV band at $330 \mathrm{~nm}$, an induction period of ca. $450 \mathrm{~s}$ is observed followed by pseudo first-order decay with a slope of $7.6( \pm 0.6) \times 10^{-3} \mathrm{~s}^{-1}$. This value is also similar to the one obtained from Figure 1 indicating that after the induction period $\mathrm{Fe}$ (II) is regenerated ${ }^{18}$ to produce $\mathrm{OH}$ as proposed in Eq. 4.

\section{Experiments varying $\mathrm{pH}$}

Kinetics, following $p$-nitrophenol absorbance $(330 \mathrm{~nm}$, at acid $\mathrm{pH}$ or $400 \mathrm{~nm}$, at neutral or basic $\mathrm{pH}$ ) vs. time at three $\mathrm{pH}: 2.8,6.3$ and 10.0 (using phosphate buffer) and 1:5:1 ratios of phenol: $\mathrm{H}_{2} \mathrm{O}_{2}: \mathrm{Fe}(\mathrm{II})$ were conducted. At neutral or basic $\mathrm{pH}$ no reduction of the $p$-nitrophenol absorbance was observed in $500 \mathrm{~s}$. Meanwhile, at $\mathrm{pH}=2.8$, a t1/2 of ca. $50 \mathrm{~s}$ is observed.

\section{NaCl Fenton inhibition}

In Figure 3 the influence of addition of $\mathrm{NaCl}$ to a reaction mixture 1:5:1, p-nitrophenol, $\mathrm{H}_{2} \mathrm{O}_{2}$, $\mathrm{Fe}(\mathrm{II})$ is shown in terms of percentage of $p$-nitrophenol transformation. For comparison, a reaction without $\mathrm{NaCl}$ is also shown. 


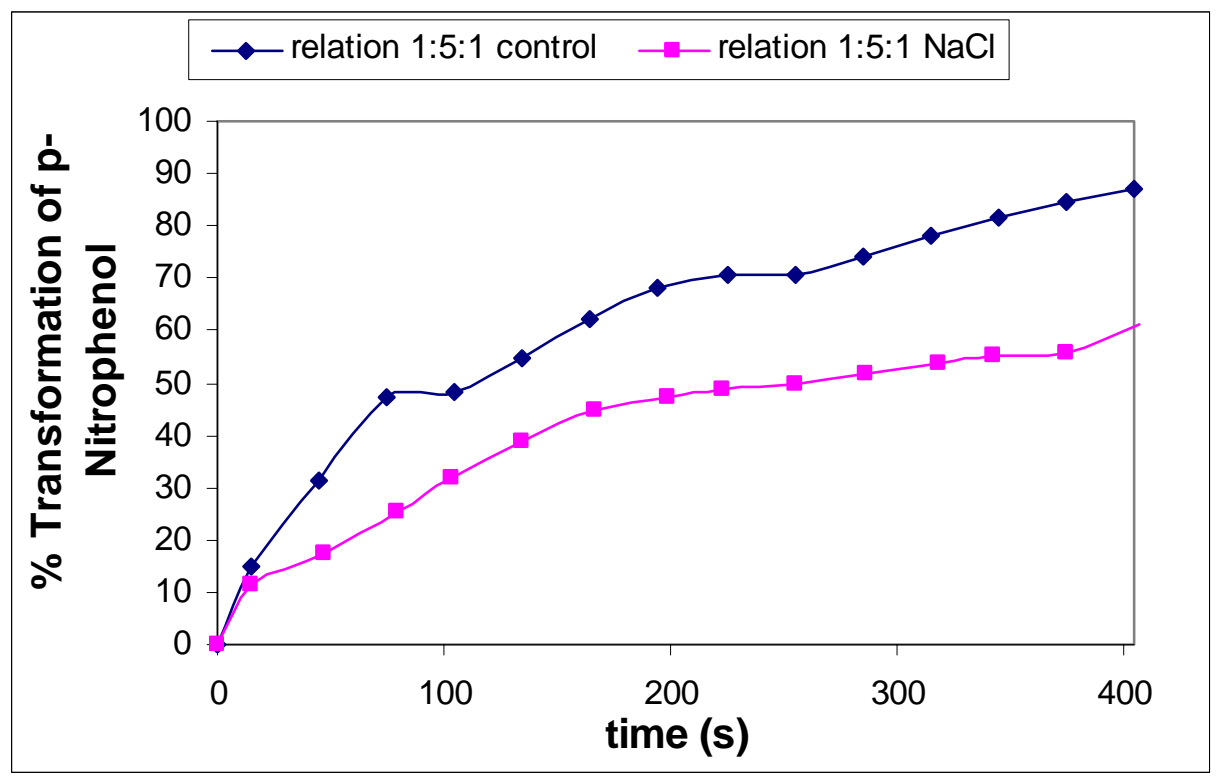

Figure 3. Fenton inhibition promoted by $\mathrm{NaCl}$ addition. Bottom line: Initial conditions: $[p-$ Nitrophenol $]=1,01( \pm 0,03) \times 10^{-4} \quad \mathrm{M},\left[\mathrm{H}_{2} \mathrm{O}_{2}\right]=5,0 \quad( \pm 0,2) \times 10^{-4} \mathrm{M}, \quad\left[\mathrm{Fe}^{+2}\right]=1,00( \pm 0,02) \times 10^{-4} \mathrm{M}$, $\left.[\mathrm{NaCl}]=1 \times 10^{-4} \mathrm{M}, \mathrm{pH}=2,8, \lambda=330 \mathrm{~nm}\right)$. Top line: without $\mathrm{NaCl} . \mathrm{pH}=2.8, \mathrm{~T}=25^{\circ} \mathrm{C}$.

According to the results, a ratio 1:5:1 (p-nitrophenol: $\mathrm{H}_{2} \mathrm{O}_{2}$ : $\mathrm{Fe}(\mathrm{II})$ ), $\mathrm{pH}$ ca. 3 and a minimum of salinity on the effluent to be treated are conditions that guarantee an efficient phenol degradation and mineralization. The rate limiting step is independent of the contaminant, therefore these conditions may also be used to degrade other contaminants.

The rate limiting step is indeed hydroxyl radical formation as it has been previously ${ }^{11-14}$ recognized. However, in this study it has been found that a pre-equilibrium between free $\mathrm{Fe}$ (II) and $\mathrm{H}_{2} \mathrm{O}_{2}$ and a $\mathrm{Fe}(\mathrm{II})-\left(\mathrm{H}_{2} \mathrm{O}_{2}\right)_{\mathrm{n}}$ is established previous to the internal electron transfer that forms hydroxyl radical and $\mathrm{Fe}(\mathrm{III})$. This equilibrium is supported by the change in observed rate with $\left[\mathrm{H}_{2} \mathrm{O}_{2}\right]$ and the observed salt effect where free species are stabilized compared to the aggregated complex. The hydroxyl radical oxidation of $p$-nitrophenol occurs in a fast step as supported by the zero order kinetic dependence on $[p \text {-nitrophenol }]^{19}$. The results also support the well recognized ${ }^{13,18}$ cyclic character of Fenton reagent in which $\mathrm{Fe}(\mathrm{II})$ is regenerated from $\mathrm{Fe}(\mathrm{III})$ in a slow reaction through $\mathrm{Fe}(\mathrm{III})-\mathrm{H}_{2} \mathrm{O}_{2}$ electron transfer.

\section{Intermediates identification}

$p$-Nitrophenol oxidation intermediates, using Fenton reagent, were identified by GC/MS using the procedure indicated in the experimental section. The identified intermediates were: $p$ nitrocatechol, hydroquinone and a dibenzofuran derivative (1,2,3,4,4a,9b-hexahydro-9-hydroxybenzo(b)benzofuranol). In Figure 4, these intermediates are shown. Mass spectrum: $\mathrm{m} / \mathrm{z}$

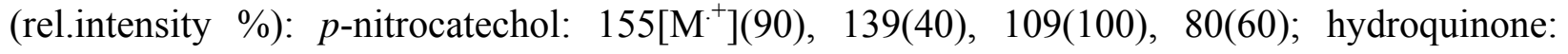


$110\left[\mathrm{M}^{+}\right](100), 81(20), 53(15)$; dibenzofuran derivative: $190\left[\mathrm{M}^{+}\right](100), 161(30), 147(70)$, 136(35), 123(25), 110(30), 77 (5), 51(5).<smiles>O=[N+]([O-])c1ccc(O)c(O)c1</smiles>

p-nitrocatechol<smiles>O=[N+]([O-])c1ccc(O)cc1</smiles><smiles>O=[N+]([O-])C1=CC(O)(O)C=CC1</smiles><smiles>O=[N+]([O-])C1=CC(O)C(O)C=C1</smiles><smiles>Oc1ccc(O)cc1</smiles>

hydroquinone

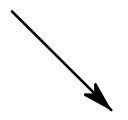<smiles>OC12CCCCC1c1ccccc1O2</smiles>

dibenzofuran derivative

Figure 4. Hydroxyl radical degradation path for p-nitrophenol. The hydroxy p-nitrophenol radical (first step) has been previously proposed ${ }^{7}$.

\section{5. p-Nitrophenol mineralization}

The rate of $p$-nitrophenol transformation in $\mathrm{CO}_{2}, \mathrm{H}_{2} \mathrm{O}$ and $\mathrm{NO}_{2}{ }^{-}$, was monitored by measuring COD (chemical oxygen demand). Using 1:5:1 and 1:8:1 (p-nitrophenol: $\mathrm{H}_{2} \mathrm{O}_{2}: \mathrm{Fe}(\mathrm{II})$ ) ratios, COD decreased 50\% (relative to the COD measurement after ca. $300 \mathrm{~s}$ ) in $35 \mathrm{~s}$. This indicates that mineralization and degradation of $p$-nitrophenol proceed at equal rates. Therefore, the rate limiting step for mineralization is also that for hydroxyl radical formation. 


\section{6. $[\mathrm{Fe}(\mathrm{II})]$ and Fenton rate}

Experiments varying $[\mathrm{Fe}(\mathrm{II})]$, show that the reaction suffers an inhibition when the $[\mathrm{Fe}(\mathrm{II})]>[p$ nitrophenol]. The $\mathrm{OH}^{-}$formed reacts with the excess of $\mathrm{Fe}(\mathrm{II})$ to produce $\mathrm{Fe}(\mathrm{III})$ and $\mathrm{OH}^{-}$. This side reaction competes with the substrate hydroxyl radical consumption. This inhibition has been also observed ${ }^{6}$ previously.

\section{Oxalic acid Fenton complex}

In Table 2, pseudo first-order rate constants obtained according to the procedure described in the experimental section, are shown. These rate constants correspond to different reaction conditions. As observed from the first two experiments, addition of oxalic acid produces appreciable increase in the kobs value. We have interpreted this increase in rate as the result of a parallel participants mechanism: the traditional $\mathrm{OH}$ formation (Eq. 4) and a $\mathrm{Fe}$ (III) formation via oxalic acid complex. Since the rate constant of the first mechanism has been measured independently (second row data in Table 2), for the last mechanism, the observed rate is given by the difference of the two first kobs values of Table 2. This kobs corresponds then to the pseudo first-rate constant of the $\mathrm{Fe}$ (II)-oxalic acid reaction path. It is worth noting that when $\mathrm{Fe}$ (III) is used to form the oxalic acid complex (last data of Table 2), p-nitrophenol degrades (without an induction period) with a rate constant very similar to that of the Fe(II)-oxalic acid path. Therefore, we conclude that Fe(III)-oxalic acid complex is a common intermediate for the Feoxalic acid path no matter what the oxidation state of Fe. In Eq. 7, the Fe-oxalic acid path proposal is shown. It has been reported ${ }^{20}$ that reaction shown in Eq. 6 proceeds rapidly.

Table 2. Pseudo first-order rate constants for the Fenton reagent reaction at different initial conditions. ${ }^{1}$ Value obtained from Figure $2 .{ }^{2}$ Value obtained from the difference of the two first values

\begin{tabular}{lc}
\hline \multicolumn{1}{c}{ Reactions in Acid Media } \\
$\mathrm{pH}=2.8, \mathrm{~T}=25^{\circ} \mathrm{C}$ & $\mathrm{k}_{\mathrm{obs}}\left(\mathrm{s}^{-1}\right)$ \\
\hline $\mathrm{Fe}(\mathrm{II})+$ Oxalic Acid $+\mathrm{H}_{2} \mathrm{O}_{2} \quad$ Molar relation & $3,3( \pm 0,2) \times 10^{-2}$ \\
$(1: 1: 14)$ & $1.5 \times 10^{-2}(1)$ \\
$\mathrm{Fe}(\mathrm{II})+\mathrm{H}_{2} \mathrm{O}_{2}$ & \\
$\begin{array}{l}\text { Molar Relation }(1: 14) \\
\mathrm{Fe}(\mathrm{II})-\text { Oxalic acid }+\mathrm{H}_{2} \mathrm{O}_{2}\end{array}$ & $1.8 \times 10^{-2}(2)$ \\
$\mathrm{Fe}(\mathrm{II})+$ Oxalic Acid $+p$-nitrophenol $+\mathrm{H}_{2} \mathrm{O}_{2}$ & $7,0( \pm 0,8) \times 10^{-3}$ \\
$\mathrm{Molar}$ Relation $(1: 1: 1: 14)$ & \\
Fe(III) + Oxalic Acid $+p$-nitrophenol $+\mathrm{H}_{2} \mathrm{O}_{2}$ & $6,7( \pm 0,5) \times 10^{-3}$ \\
Molar Relation $(1: 1: 1: 14)$ & \\
\hline
\end{tabular}


$\mathrm{Fe}(\mathrm{II})+$ Oxalic acid $\stackrel{\mathrm{H}_{2} \mathrm{O}_{2}}{\longleftrightarrow} \mathrm{Fe}(\mathrm{II})$-oxalic acid- $\mathrm{H}_{2} \mathrm{O}_{2} \longrightarrow$ Fe(III)-oxalic acid $+\mathrm{OH}^{-}+\mathrm{OH}^{-}$

$$
\text { Fe(III)-oxalic acid } \stackrel{\mathrm{H}_{2} \mathrm{O}_{2}}{\longleftrightarrow} \mathrm{Fe}(\mathrm{III}) \text {-oxalic acid- } \mathrm{H}_{2} \mathrm{O}_{2}
$$

We have also followed the reaction potential to donate electrons through the measurement of COD (chemical oxygen demand). Under conditions in which Fe(II) or Fe(III) are mixed with an excess of $\mathrm{H}_{2} \mathrm{O}_{2}$, an important increase of COD occurs during the first $20 \mathrm{~s}$ of the reaction time. After that time, COD remains constant for more that $300 \mathrm{~s}$. Formation of the oxalic acid-Fe complex itself does not produce COD increase, as it has been found in an additional experiment. It has also been reported ${ }^{4}$ that Fenton reagent does not oxidize oxalic acid. Therefore, a new complex such as the one proposed in Eq. 7 must be formed. This Fe-oxalic acid- $\mathrm{H}_{2} \mathrm{O}_{2}$ complex may suffer internal electron transfer to produce an $\mathrm{Fe}(\mathrm{IV})$ radical species that increases COD via intermolecular electron transfer to an oxidant agent $\left(\mathrm{O}_{2} / \mathrm{H}_{2} \mathrm{O}\right)$. It has been reported ${ }^{14,17}$ that the $\mathrm{Fe}(\mathrm{IV})$ species are unstable. For instance, it is not formed when $\mathrm{Fe}(\mathrm{III})$ is treated with $\mathrm{H}_{2} \mathrm{O}_{2}$. Instead of further $\mathrm{Fe}$ (III) oxidation, this species is reduced to yield $\mathrm{Fe}(\mathrm{II})$ and superoxide anion radical. However, when oxalic acid is added Fe(IV) could be formed due to an intramolecular delocalization of the electron coming from Fe. This delocalized Fe(IV) species represents a alternative path for oxidation in which the oxidant is this species instead of hydroxyl radical. Some experimental evidence supports the involvement of this alternative path: 1.- When Fe(III), oxalic acid and $\mathrm{H}_{2} \mathrm{O}_{2}$ are mixed with $p$-nitrophenol, immediate degradation of the phenol is observed. Therefore, $\mathrm{Fe}$ (III) is not reduced to $\mathrm{Fe}(\mathrm{II})$ by $\mathrm{H}_{2} \mathrm{O}_{2}$ when oxalic acid is added to the reaction mixture. Otherwise, an induction period (such as the one obtained when Fe(III) and $\mathrm{H}_{2} \mathrm{O}_{2}$ are mixed) would have been observed. 2.- When Fe(III), oxalic acid, $\mathrm{H}_{2} \mathrm{O}_{2}$ and $p$ nitrophenol are mixed, an increase of the COD of the mixture is observed after ca. 20-30 s. (Figure 5). 3.- When $\mathrm{Fe}(\mathrm{II})$ or $\mathrm{Fe}$ (III) are mixed with oxalic acid and $\mathrm{H}_{2} \mathrm{O}_{2}$, an immediate (ca.30 s) increase in the COD is observed. All these results are in agreement with the reaction paths shown in Figure 6. In the $\mathrm{Fe}(\mathrm{III})$-oxalic acid- $\mathrm{H}_{2} \mathrm{O}_{2}$ complex formed, an internal electron transfer occurs to form the $\mathrm{Fe}(\mathrm{IV})$ species that is stabilized by electron delocalization through the carboxylic group. As shown in Figure 6 (path a), an oxidizing agent such as $\mathrm{O}_{2}$ could be consumed (increasing COD) accepting the delocalized electron to yield $\mathrm{H}_{2} \mathrm{O}_{2}, 2 \mathrm{CO}_{2}$ (from oxalic acid) and $\mathrm{Fe}(\mathrm{III})$. The complex may also act as oxidant accepting an electron from $p$ nitrophenol to produce a radical cation that finally produces cathecol radical from where oxidation continues. 


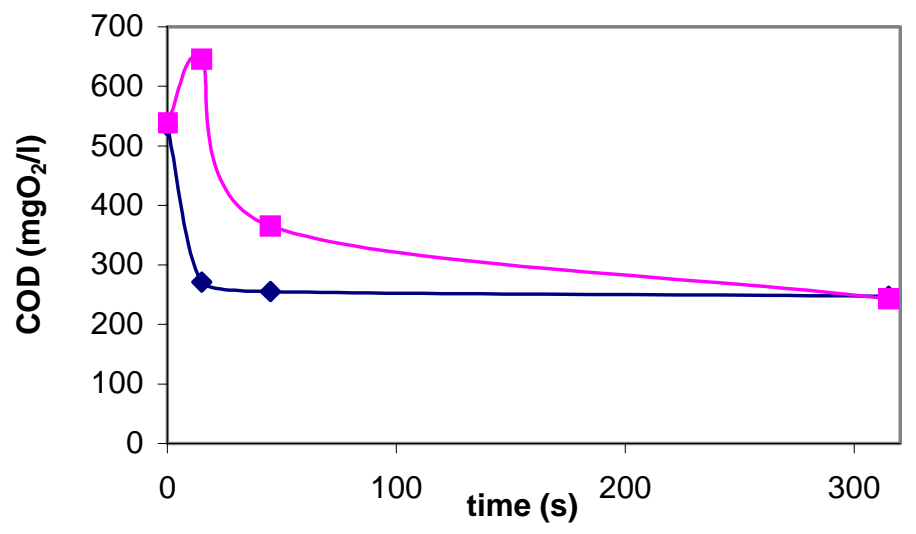

Figure 5. Chemical oxygen demand (COD) vs. time plot. Top line: $\mathrm{Fe}(\mathrm{III})$ :oxalic acid: $\mathrm{H}_{2} \mathrm{O}_{2}$ : $p$ nitrophenol (1:1:5:1) Bottom line: $\mathrm{Fe}(\mathrm{II})$ :oxalic acid: $\mathrm{H}_{2} \mathrm{O}_{2}: p$-nitrophenol (1:1:5:1). $\mathrm{T}=25^{\circ} \mathrm{C}$. $\mathrm{pH}=2.8$.

As shown in Figure 5 , the initial (after ca. 20 s) COD increase is not observed in the case of $\mathrm{Fe}(\mathrm{II})$ when $p$-nitrophenol is added to the reaction mixture. This is probably due to the immediate consumption of $p$-nitrophenol via the hydroxyl radical that is produced before the Fe(III)-oxalic acid $-\mathrm{H}_{2} \mathrm{O}_{2}$ complex is formed. When $p$-nitrophenol is not added to the reaction mixture the increase in COD is observed no matter what the oxidation state of Fe. This is indeed an indication that even when $\mathrm{Fe}$ (II) is used, the $\mathrm{Fe}(\mathrm{III}) / \mathrm{Fe}(\mathrm{IV})$ complex (Figure 6) is formed. In fact, its contribution in terms of kobs value is comparable (as shown in Table 2) to the hydroxyl radical path.

\section{Conclusions}

In this work, we have found that the rate limiting step in the Fenton reagent reaction is the hydroxyl radical formation from a $\mathrm{Fe}(\mathrm{II})-\left(\mathrm{H}_{2} \mathrm{O}_{2}\right)_{\mathrm{n}}$ complex which is in equilibrium with the $\mathrm{Fe}(\mathrm{II})$ and $\mathrm{H}_{2} \mathrm{O}_{2}$ free species. For $\mathrm{n}>10$, no further increase in the $\mathrm{k}_{\mathrm{obs}}$. is obtained. The reaction is inhibited when $\mathrm{NaCl}$ is added due to the destabilization of the less solvated $\mathrm{Fe}$ (II) free species when compared to the aggregated form. The reaction is acid catalyzed in agreement with $\mathrm{OH}^{-}$ formation as one of the reaction products. When $\mathrm{Fe}(\mathrm{III})$ is used, instead of $\mathrm{Fe}$ (II) no reaction is observed during a period of $500 \mathrm{~s}$. After that period, oxidation of $p$-nitrophenol, at $\mathrm{pH}=2.8$ occurs with kobs similar to the Fe(II), Fenton reagent one $\left(2.3 \times 10^{-2} \mathrm{~s}^{-1}\right)$. The observed induction period corresponds to the $\mathrm{Fe}(\mathrm{III})$ and $\mathrm{H}_{2} \mathrm{O}_{2}$ reaction to yield $\mathrm{Fe}(\mathrm{II})$ and the protonated form of the superoxide radical anion. When oxalic acid is added to the reaction mixture, an alternative oxidation path occurs with a kobs $=1.8 \times 10^{-2} \mathrm{~s}^{-1}$. This alternative pathway consists of Fe(III)oxalic acid- $\mathrm{H}_{2} \mathrm{O}_{2}$ complex formation. An intramolecular electron transfer in the complex is proposed in order to explain the immediate reaction when Fe(III) is used instead of Fe(II) and the 
initial increase of COD (chemical oxygen demand) when $p$-nitrophenol is absent or in its presence when $\mathrm{Fe}(\mathrm{III})$ is used.

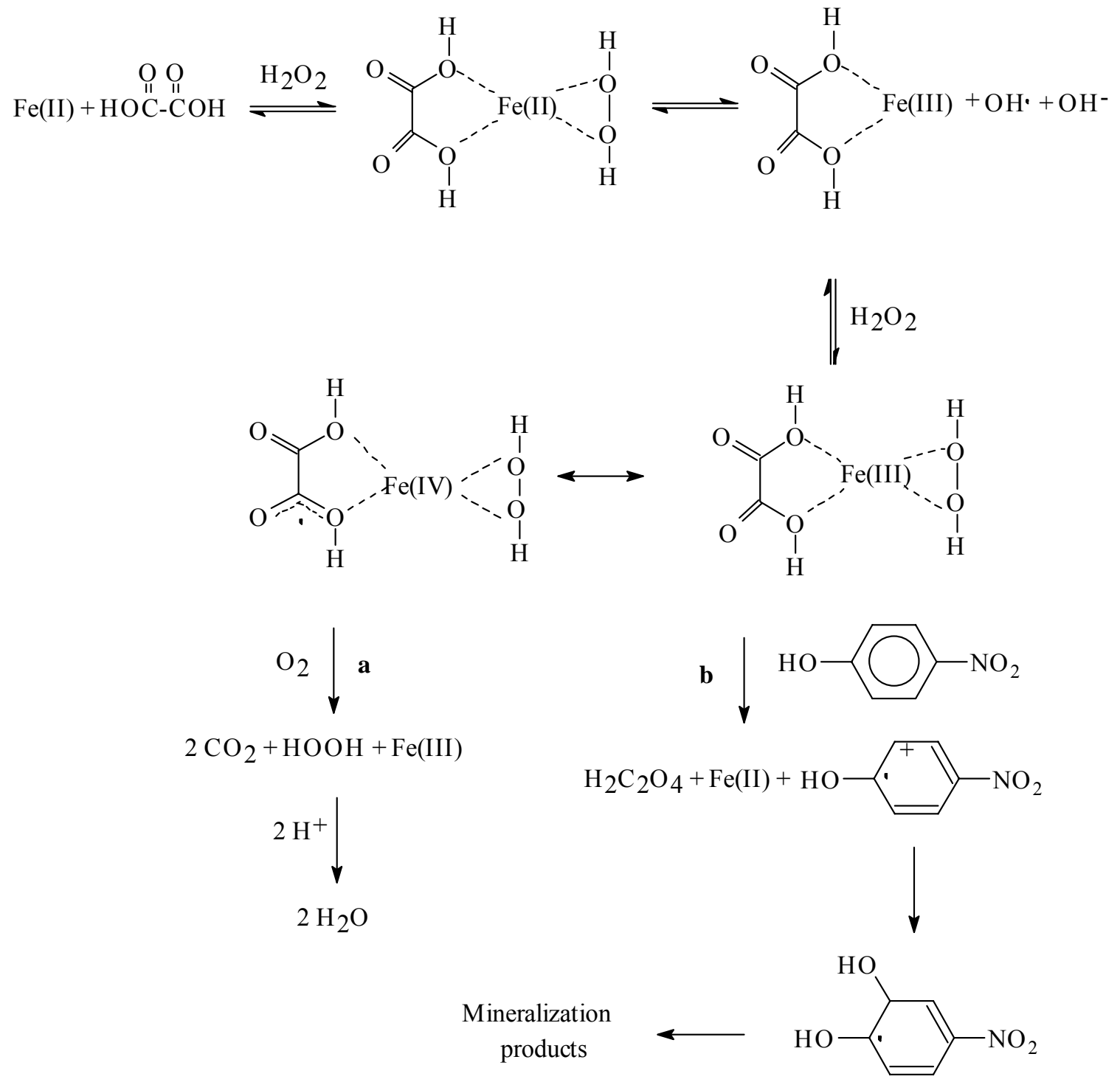

Figure 6. Fenton reagent reaction in presence of oxalic acid. $\mathrm{Fe}(\mathrm{III})$-oxalic acid- $\mathrm{H}_{2} \mathrm{O}_{2}$ is the key intermediate. Path a explains the observed initial increment of COD. Path $\mathbf{b}$ illustrates the oxidizing properties of the complex.

\section{Experimental Section}

\section{Fenton experiments}


Fresh, $\mathrm{FeSO}_{4} \cdot 7 \mathrm{H}_{2} \mathrm{O}$ (from Scharlau) solutions were prepared before kinetics runs. $\mathrm{pH}$ was adjusted with $\mathrm{H}_{2} \mathrm{SO}_{4}$ 0.1 M solution. UV-visible (Hewlett Packard, model $8452 \mathrm{~A}$, diode array) was used to monitored reaction progress by following either the Fe (III) band at $220 \mathrm{~nm}$ or the $p$ nitrophenol degradation at $330 \mathrm{~nm}$. In experiments without adding p-nitrophenol, $\mathrm{H}_{2} \mathrm{O}_{2}$ (from Riedel de Haén, 35\%) was added to the Fe (II) solution previously prepared in a UV quartz cell. Added volumes were taken into account to the reactants final concentrations. Reaction was monitored each $8 \mathrm{~s}$ during the first $8 \mathrm{~min}$ and each $60 \mathrm{~s}$ during the following $30 \mathrm{~min}$. Triplicates of each experiment were used to evaluate the mean and standard deviation of the rate constants. Rate constants were obtained from the slope of $\ln \left(\mathrm{A}_{\text {inf. }}-\mathrm{At}\right)$ vs. $\mathrm{t}$ plots (A; absorbance). In reactions in which $p$-nitrophenol was included, solution were prepared in the UV quartz cell together with the $\mathrm{Fe}$ (II) solution. To the mixture, $\mathrm{H}_{2} \mathrm{O}_{2}$ solution was added and the reaction was monitored by following $p$-nitrophenol absortion band $(330 \mathrm{~nm})$. 1:1:1 (phenol: $\mathrm{H}_{2} \mathrm{O}_{2}: \mathrm{Fe}(\mathrm{II})$ ) and 1:5:1 molar ratios were used. Reactions were monitored each $30 \mathrm{~s}$ during the first $12 \mathrm{~min}$ and each $60 \mathrm{~s}$ for additional $12 \mathrm{~min}$. Rate constants were obtained from plots of $1 \mathrm{n}$ [phenol] vs. $t$. Previously, A (absorbance) vs. [phenol] calibration curves were obtained. Reactions with Fe(III) $\left(\mathrm{Fe}_{2}\left(\mathrm{SO}_{4}\right)_{3} \cdot \mathrm{xH}_{2} \mathrm{O}\right)$, from Riedel de Haén) were conducted using the same experimental conditions as when Fe(II) was used. The reaction was quenched by adding methanol (98\%, from Riedel de Haén). Reactions with oxalic acid were conducted using the following Fe:oxalic acid: $\mathrm{H}_{2} \mathrm{O}_{2}$ ratios: 1:1:14 and when phenol was included, phenol: $\mathrm{H}_{2} \mathrm{O}_{2}:$ Fe:oxalic acid: 1:5:1:1.

In order to optimize reaction conditions, experiments varying $\left[\mathrm{H}_{2} \mathrm{O}_{2}\right]$ at the following phenol $\left(1.2 \times 10^{-2} \mathrm{M}\right): \mathrm{H}_{2} \mathrm{O}_{2}: \mathrm{Fe}(\mathrm{II})$ ratios, were performed: 1:0:1, 1:5:1, 1:8:1, 1:11:1, 1:14:1, 1:17:1 and $1: 20: 1$. [Fe(II)] was also varied according to the following ratios: 1:14:0, 1:14:0.25, 1:14:0.5, $1: 14: 0.75,1: 14: 1$ and $1: 14: 1.5$. A ratio of $1: 5: 1,[\mathrm{NaCl}]: 1.0 \times 10^{-4} \mathrm{M}$ was used and $\mathrm{pH}(2.8,6.28$ and 10, adjusted with phosphate buffer) at reactants ratio:1:5:1 were used to conduct experiments.

\section{Reaction intermediates identification}

$p$-Nitrophenol reaction intermediates identification at the reaction ratio: phenol $\left(1.2 \times 10^{-2}\right.$ M): $\mathrm{H}_{2} \mathrm{O}_{2}: \mathrm{Fe}(\mathrm{II}): 1: 0: 1,1: 0.5: 1,1: 1: 1,1: 2: 1$ and 1:5:1 was made as followed: $15 \mathrm{~s}$ after reaction initiation, $0.5 \mathrm{ml}$ of methanol was added. Extraction was carried out with dichloromethane (HPLC grade $99.8 \%$ from Merck). The organic layer was dried with anhydrous sodium sulfate and the solvent evaporated by means of Tymark turbo vap II solvent concentrator at $25^{\circ} \mathrm{C} .5 \mathrm{uL}$ extracts were injected $\left(300^{\circ} \mathrm{C}\right)$ into a GC/MS Hewlett Packard chromatograph model HP 6890 provided with a mass detector model HP 5973. Helium was used as carrier at $1 \mathrm{ml} / \mathrm{min}$. A $30 \mathrm{~m} \mathrm{x}$ $0.25 \mathrm{~mm}$ DB-5625 column was used with the following temperature arrangement: $10 \mathrm{~min}$ at $135{ }^{\circ} \mathrm{C}, 20{ }^{\circ} \mathrm{C} / \mathrm{min}$ until reach $280{ }^{\circ} \mathrm{C}$ and additional $5 \mathrm{~min}$ at that temperature. Mass detector was operated in scan mode (28-300 mau) in selective ion monitoring mode at $70 \mathrm{ev}$.

\section{Mineralization experiments}

Mineralization experiments were run under identical conditions to degradation experiments. However, the reaction was monitored measuring COD (chemical oxygen demand) using an 
$\mathrm{HACH}$ colorimetric method: $2 \mathrm{ml}$ of sample is digested with $\mathrm{HACH} \mathrm{K}_{2} \mathrm{Cr}_{2} \mathrm{O}_{7}$ solution at $150{ }^{\circ} \mathrm{C}$ for $2 \mathrm{~h}$. The $\mathrm{Cr}$ (III) formed is followed at $620 \mathrm{~nm}$ using a HACH DR/2010 spectrophotometer.

\section{Acknowledgements}

We acknowledge UGA-USB, INTEVEP and CONIPET (project: 97-003767), for the financial support.

\section{References and Notes}

1. Fenton, H.J.H. J. Chem. Soc. 1894, 65, 899.

2. López, R.; Núñez, O.; Morales, F.; Calderón, C.; Liewald, W. Acta Científica Venezolana 1999, 50, 1, 75.

3. Safarzadeh-Amiri, A.; Bolton, J.; Cater, S. J. Adv. Oxid. Technol. 1996, 1,1,18.

4. Bigda, R. Chem. Eng. Prog. 1995, 62.

5. Rahhal, S.; Richter, H. J. Am. Chem. Soc. 1988, 110, 3126.

6. Ma, Y.; Huang, S.; Lin, J. Water Science \& Technology 2000, 42, 3-4, 1155.

7. Oturan, M.; Peiroten, J. ; Chartrin P.; Acher, A. Environ. Sci. Technol. 2000, 34, 3474.

8. Sedlak, D.; Andren A. Environ. Sci. Technol. 1991, 25, 4, 777.

9. Barbeni, M.; Minero, C.; Pelizzetti, E. Chemosphere 1987, 16, 2225.

10. Tyre, B.; Watts, R. ; Miller, G. J. Environ. Qual. 1991, 20, 832.

11. Merz, J.H.; Waters W.A. Discuss. Faraday Soc. 1947, 2, 179.

12. Haber F.; Weiss J.J. Proc. Roy. Soc. London, Ser. A. 1934, 147, 332.

13. Walling, C. Acc. Chem. Res. 1975, 8, 125.

14. Walling, C.; Amarnath, K. J. Am. Chem. Soc. 1982, 104, 1185.

15. Yamazaki, I.; Piette, L. J. Biochem. Chem. 1990, 265, 23, 13589.

16. Groves, J.T.; Vander Puy. M. J. Am. Chem. Soc. 1976, 98, 5290.

17. Groves, J.T.; Nemo T.E.; Meyer, R.S. J. Am. Chem. Soc. 1979, 101, 1032.

18. Walling, C.; Goosen, A. J. Am. Chem. Soc. 1973, 95, 9987.

19. The kobs. is independent on [ $p$-nitrophenol]; however, a plot of $\ln [p$-nitrophenol] vs. $t$ corresponds to a typical pseudo first-order plot since the radical, that is consumed rapidly by $p$-nitrophenol, is produced in the rate limiting step under first order conditions.

20. Zuo, Y.Y.; Hoigné, J. Environ. Sci. Technol. 1992, 26, 5, 1014. 